\title{
New raw material for activated carbon. I. Methylene blue adsorption on activated carbon prepared from Khaya senegalensis fruits
}

\author{
Casmir E. Gimba ${ }^{1}$, Odike Ocholi ${ }^{1}$, Peter A. Egwaikhide², Turoti Muyiwa ${ }^{3}$, \\ and Emmanuel E. Akporhonor ${ }^{4}$ \\ ${ }^{1}$ Department of Chemistry, Ahmadu Bello University, Zaria , Nigeria. \\ ${ }^{2}$ Department of Chemistry and Centre for Biomaterial Research, University of Benin, Nigeria. \\ ${ }^{3}$ Department of Chemistry, Obafemi Awolowo University, Ile-Ife, Nigeria. \\ ${ }^{4}$ Department of Chemistry, Delta State University, Abraka, Nigeria.
}

\begin{abstract}
C. E. Gimba, O. Ocholi, P. A. Egwaikhide, T. Muyiwa, and E.E. Akporhonor. 2009. New raw material for activated carbon. I. Methylene blue adsorption on activated carbon prepared from Khaya senegalensis fruits. Cien. Inv. Agr. 36(1):107-114. Activated carbons were prepared from Khaya senegalensis fruits. Carbonization and activation temperatures were $500^{\circ} \mathrm{C}$ and $800^{\circ} \mathrm{C}$, respectively, at residence time of $5 \mathrm{~min}$ for each process. Activating agents were $1 \mathrm{M}$ each of $\mathrm{NaCl}, \mathrm{KCl}, \mathrm{CaCl}_{2}, \mathrm{MgCl}_{2} .6 \mathrm{H}_{2} \mathrm{O}, \mathrm{Na}_{2} \mathrm{CO}_{3}, \mathrm{~K}_{2} \mathrm{CO}_{3}, \mathrm{H}_{2} \mathrm{SO}_{4}$, and $\mathrm{ZnCI}_{2}$. Particle size was $125 \mu \mathrm{m}$ and adsorption studies were carried out using methylene blue in aqueous solution as adsorbate through fixed beds in micro columns. Equilibrium data were analyzed using adsorption intensity and capacity parameters from the Freundlich isotherms as well as breakthrough curves. Results were compared with performances of commercial animal charcoal and granular activated carbon. The results suggest that $K$. senegalensis fruits are suitable raw materials for producing activated carbons. The NaCI activated carbon has the best adsorption characteristics which are better than the commercial products.
\end{abstract}

Key words: Activation, adsorption, carbonization, isotherm Khaya senegalensis.

\section{Introduction}

It has been reported that the global consumption of activated carbon (AC) was above 500,300 t as at 2003, and it is expected to rise annually by 7\% (Maroto-Valer et al., 2001). Due to increasing market demand, cheap and readily available alternative precursors are sought while methods of production are developed.

Received 17 April 2008. Accepted 12 August 2008. Corresponding author: turoti07muyiwa@yahoo.co.uk.
Khaya plants, Khaya senegalensis (=Swietenia Senegalensis Desr), is a indigenous hardwood tree of Africa belonging to the family Meliaceae that thrives well in northern Nigeria. It is relatively abundant in Ahmadu Bello University Zaria, Nigeria, the locality where this study was conducted. The roots, wood, stem, bark, leaves, and seeds are used for varios medicinal and domestic purposes (von Maydell, 1990). The fatty acid composition of the seed oil has been investigated previously, and it is composed of stearic acid, palmitic acid, oleic acids and an unidentifiable acid (Okieimen and Eromosele, 1999). However, the fruits, which are globose capsules, have not been reputedly studied like 
other parts of the tree. They are considered as garbage or waste which constitutes an environmental problem as much time, money and effort is spent on their disposal. A fully mature tree produces between 200 to 500 or even more fruits per year. The average diameter of a fruit is $4.5 \pm 0.17 \mathrm{~cm}$ and dry weighs $31.88 \pm 3.34 \mathrm{~g}$.

Considering that other parts of the khaya plants have been employed in medicine and many other areas, it was postulated that fruit were possible to use as an adsorbent, particularly when most of the uses of activated carbons are basically expected to be dependent on their adsorption activities. Consequently, the main objectives of this work were to investigate the adsorption characteristics of $K$. senegalensis fruits using methylene blue (MB) by fixed-beds in columns, and to compare the results obtained from AC's prepared with commercial products.

\section{Materials and methods}

\section{Preparation of the raw material}

Fruit samples were collected around the residential quarters of Ahmadu Bello University Zaria, Nigeria, between December 2004 and March 2005. Fruits were picked, washed and sun-dried before to broken them into small piece sizes with a wooden mortar and pestle and further pulverized into powdered form using a Siebtechnik Milling Machine and sieved into particle size of $125 \mu \mathrm{m}$ with an Endecotts sieve.

\section{Controls}

Commercial powdered animal charcoal (Fischer Ltd. England) was purchased in Nigeria (Cardinal Chemical Supplies Company Zaria, Nigeria), and served as the first commercial control (Control 1). The Control 2 was commercial granular AC (Steve Moore Chemical Company Zaria, Nigeria). The particle size of Control 1 is less than $125 \mu \mathrm{m}$ while particle size of Control 2 was $425 \mu \mathrm{m}$.

\section{Carbonization}

Raw sample was weighed ( $3 \mathrm{~g}$ ) into six separate copper crucibles and introduced into a Muffle furnace at $500^{\circ} \mathrm{C}$ for $5 \mathrm{~min}$ after which they were then removed and quenched in cold water and sun dried (Gimba et al., 2001). The procedure was repeated until substantial amount of carbonized sample was obtained. This was stored in sealed plastic containers.

\section{Characterization of the carbonized carbon}

Elemental analysis. Elemental analysis of the raw and carbonized samples was done by neutron activation analysis at the reactor facility section of Centre for Energy Research and Training (CERT) (Ahmadu Bello University Zaria, Nigeria). The long regime irradiation through a thermal neutron flux was used.

Moisture and dry matter content. An amount of $1.0 \mathrm{~g}$ each of the carbonized $K$. senegalensis fruits samples was placed in a clean silica crucible that was previously dried in a desiccator and weighed. They were then dried in an aircirculated oven at $105^{\circ} \mathrm{C}$ for $3 \mathrm{~h}$ after which they were cooled in a desiccator and then weighed. Results were expressed as percentage of the initial weight carbonized samples.

Ash content. Copper crucibles were heated in a furnace at $500^{\circ} \mathrm{C}$, then cooled in a desiccator and weighed. The oven dried samples from the previous section were placed in the crucible and transferred into the Muffle furnace at $900^{\circ} \mathrm{C}$ for $3 \mathrm{~h}$. The crucibles/content were allowed to cool in a desiccator and then weighed to obtain the weight of the ash. The ash content was expresses as percentage of the oven dry weight.

Bulk density. The volume of distilled water displaced by a known mass of the carbonized sample was measured using a measuring cylinder. 


\section{Activation of carbonized carbon sample}

The activation of the carbonized carbon was executed as described earlier (Gimba et al., 2001) using decimolar amounts of each of the following activating agents: $\mathrm{NaCl}(5.85 \mathrm{~g}), \mathrm{KCl}(7.45$ g), $\mathrm{CaCI}_{2}(11.1 \mathrm{~g}), \mathrm{ZnCI}_{2}(13.6 \mathrm{~g}), \mathrm{K}_{2} \mathrm{CO}_{3}(13.8 \mathrm{~g})$, $\mathrm{Na}_{2} \mathrm{CO}_{3}(10.6 \mathrm{~g}), \mathrm{H}_{2} \mathrm{SO}_{4}$, and $\mathrm{MgCI}_{2} \cdot 6 \mathrm{H}_{2} \mathrm{O}(20.3$ g) (Table 2). Flaky pastes were made by mixing $2 \mathrm{~g}$ of carbonized samples with $2 \mathrm{~mL}$ of $1 \mathrm{M}$ of each of the activating agent solutions that were prepared by dissolving the indicated amount in $60 \mathrm{~mL}$ distilled water, transferred to a $100 \mathrm{~mL}$ volumetric flask, shaken and made up to the mark with the water.

The mixture was introduced into a Carbolite furnace at $800^{\circ} \mathrm{C}$ for $5 \mathrm{~min}$ after which they were quenched with cold water, washed with distilled water and allowed to dry at room temperature. These AC samples were stored in sealable air tight polythene bags.

\section{Preparation of methylene blue stock solution}

The use of methylene blue (MB) to evaluate the adsorption characteristics of carbon has been employed. A mass of $0.12 \mathrm{~g}$ of MB (molar mass $=319.8 \mathrm{~g}$ ) was dissolved in about $10 \mathrm{~mL}$ of distilled water, transferred into a $100 \mathrm{~mL}$ volumetric flash, shaken and made up as above.

Preparation of columns using the test activated carbons and the controls

Clean columns were bedded with ground glass loaded with $60 \mathrm{mg}$ of each activated carbon sample and then equilibrated with $2.0 \mathrm{~mL}$ of distilled water.

\section{Test performed}

For each performed, 2.0, 4.0, 6.0 or $8.0 \mathrm{~mL}$ of appropriately diluted MB stock solution were passed through the equilibrated column and the absorbance of the effluent taken using a Sherwood 254 digital colorimeter at wave length $(\lambda)$ $=600 \mathrm{~nm}$. The latter was the $\lambda_{\max }$ previously determined in an absorbance-concentration experiment of the MB (adsorbate) solutions. The effluent concentration of the MB was obtained from a calibration curve previously constructed. Three separate determinations were made for each sample and average value obtained.

\section{Performance evaluation}

The performance (\%) of each matrix was calculated using the formula below:

Amount of MB adsorbed x 100 / Total amount of MB.

\section{Isotherms and breakthrough curves}

For adsorption isotherm, $x / m$ was plotted against $C$, where $x$ was the amount of MB adsorbed in $\mu \mathrm{mol}, m$ was the mass of adsorbent and $C$ was the amount of MB that was unadsorbed. The $\log _{10} x / m$ was plotted against $\log _{10} C$ to obtain the Freundlich's isotherm from where the slope $(n)$ and intercept $(k)$ were obtained from the computer plots. The $n$ and $k$ values were the parameters used in this aspect of the study. Break through curves were the plots of $\mathrm{Cx} / C_{s}$ against volume of adsorbate, where $C x$ was the effluent concentration and Cs was the influent concentration.

\section{Results and discussion}

The average values of moisture and ash content of the raw $K$. senegalensis fruits were 6.17 and $3.09 \%$, respectively (Table 1 ). The carbon yield was $17.32 \%$. While the moisture and ash content are were 6.17 and $3.09 \%$, respectively. The yield of carbon was $17.32 \%$, greater than those reported earlier using coconut shell as raw material (Gimba et al., 2001). 
Table 1. Physico-chemical properties of sample fruits of Khaya senegalensis.

\begin{tabular}{ll}
\hline Properties & Values \\
\hline Moisture content, \% & 6.17 \\
Dry matter, \% & 93.84 \\
Ash content, \% & 3.09 \\
Bulk density, g. mL-1 & 0.81 \\
Carbon yield, \% & 17.32 \\
Raw sample, pH & 5.18 \\
Carbonized sample, pH & 9.10 \\
KSF-NaCl-AC, $\mathrm{pH}$ & 9.90 \\
Control1 1, pH & 8.32 \\
Control1 2, pH & 7.25 \\
\hline
\end{tabular}

${ }^{\mathrm{I}}$ Control 1 = Commercial powdered animal charcoal (Fischer Ltd. England) Control 2 = commercial granular AC (Steve Moore Chemical Company Zaria, Nigeria).

The previous (Gimba et al., 2001).and present results show that the lower the moisture and ash content the greater the \% yield of carbonized carbon. It is therefore most probable that fruits of $K$. senegalensis are a better raw material source for producing greater yield of carbon than coconut shell under similar experimental conditions. However the present results are comparable with those reported by Tsai et al. (2001) in which corn cobs were used as the precursor.

There was a change from the acidic raw material $(\mathrm{pH}=5.18)$ to the basic carbonized product $(\mathrm{pH}=9.10)$ and to a more basic activated product. For instance, in the KSF-NaCl-AC the $\mathrm{pH}$ $=9.90$ (Table 1). This is in agreement with earlier work (Cheremisinoff and Ellerbusch, 1978) which showed that alkaline surfaces are characteristic of carbons having vegetable origins. The amount of MB adsorbed is expected to be more favorable as the carbon surfaces become more alkaline (Abram, 1973). The relatively high bulk density of $0.81 \mathrm{~g} \cdot \mathrm{mL}^{-1}$ indicates longer period of filtration cycle (Abram, 1973).

With the exception of $\mathrm{Br}, \mathrm{La}$ and $\mathrm{Sm}$, the element contents were smaller in the raw materials than in the carbonized product (Table 2). The latter generally had about three times the amount of all the other elements detected in the raw fruit samples of $K$. senegalensis. For $\mathrm{Na}$, its amount was about five times in the carbonized than in the raw. It could be that the carbonization process made the affected elements more vulnerable to detection by reducing the amount of interfering or masking agents such as the protein/volatile components of the raw fruit samples of $K$. senegalensis (Mozammel and Masahirom, 2002). Out of the ten elements detected by the method of analysis, $\mathrm{K}$ was the most abundant while $\mathrm{Sm}$ was the least abundant in both the raw and carbonized fruit samples. These results were preliminary studies for the characterization of the carbonized carbon from this new source of carbon that can be used for preparing activated carbon.

Table 2. Elemental analysis of raw and carbonized fruit samples of Khaya senegalensis.

\begin{tabular}{lll}
\hline \multirow{2}{*}{ Elements } & \multicolumn{2}{c}{ Fruit samples $^{1}$} \\
\cline { 2 - 3 } & $\mathrm{Raw}$ & $\begin{array}{l}\text { Carbonized } \\
\mathrm{mg}\end{array}$ \\
\hline $\mathrm{Al}$ & $212.6 \pm 5.9$ & $598.8 \pm 8.4$ \\
$\mathrm{Ca}$ & $4493.0 \pm 315.0$ & $13920.0 \pm 557.0$ \\
$\mathrm{Mg}$ & $339.8 \pm 108.7$ & $904.0 \pm 136.0$ \\
$\mathrm{~K}$ & $10580.0 \pm 360.0$ & $29250.0 \pm 55.0$ \\
$\mathrm{Fe}$ & $\mathrm{nd}$ & nd \\
$\mathrm{Na}$ & $37.9 \pm 21.1$ & $190 \pm 5.0$ \\
$\mathrm{Cl}$ & $1954.0 \pm 53.0$ & $3163.0 \pm 73.0$ \\
$\mathrm{As}$ & nd & nd \\
$\mathrm{La}$ & $3.44 \pm 0.0$ & $2.74 \pm 0.11$ \\
$\mathrm{Cr}$ & nd & nd \\
$\mathrm{Sm}$ & $0.43 \pm 0.02$ & $0.22 \pm 0.001$ \\
$\mathrm{Br}$ & $7.75 \pm 0.27$ & $6.94 \pm 0.21$ \\
\hline
\end{tabular}

${ }^{1}$ Means \pm standard deviation. $\mathrm{nd}=$ below detection level.

For the purpose of clarity of presentation of results, most of the latter are conveniently presented in two groups (Figures 1,2). One group for $\mathrm{K}$. senegalensis fruits carbon activated with $\mathrm{NaCl}, \mathrm{KCl}, \mathrm{CaCl}_{2}$, and $\mathrm{MgCl}_{2} \cdot 6 \mathrm{H}_{2} \mathrm{O}$ and the second group with $\mathrm{Na}_{2} \mathrm{CO}_{3}, \mathrm{~K}_{2} \mathrm{CO}_{3}, \mathrm{H}_{2} \mathrm{SO}_{4}$ and $\mathrm{ZnCl}_{2}$ as the activating agents.

The MB adsorption isotherms showed that the order of adsorption was the same as that of the performance in the previous section and indicate the validity of the performance evaluation (Figure 1,2). The adsorption isotherms of most of the KSF-AC show that the adsorption of the 


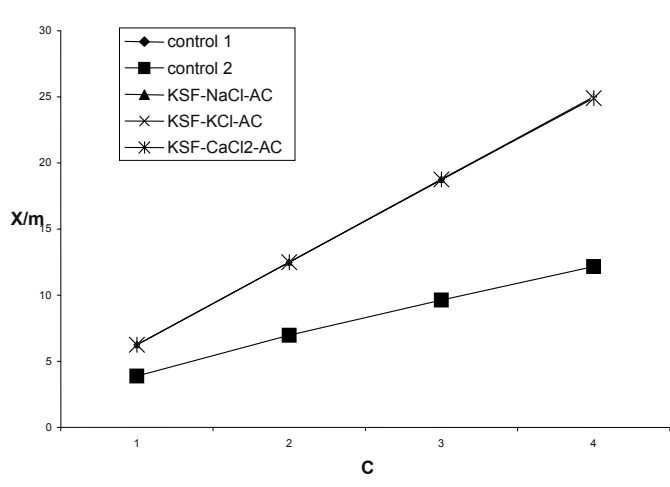

Figure 1. Adsorption isotherms of methylene blue adsorption on controls (1 and 2), KSF-NaCl-AC, KSF-KCl$\mathrm{AC}$, and $\mathrm{KSF}-\mathrm{CaCl} 2-\mathrm{AC}$ at $298 \mathrm{~K}$.

adsorbate (MB) was that of the C-1 curves (linear curves) of the General Adsorption Isotherms (Giles et al., 1960).This means that the MB penetrates into the $\mathrm{AC}$ more than the solvent (water) in line with (Mozammel and Masahirom, 1978) as the adsorption is dependent on the concentration of the adsorbate. The non-linear adsorption isotherm of $\mathrm{MgCl}_{2} \cdot 6 \mathrm{H}_{2} \mathrm{O}-\mathrm{AC}$ indicates unfavorable adsorption of the adsorbate by this matrix.

The order of $n$ values (Table 3) of MB adsorption by the $\mathrm{AC}$, in terms of the $\mathrm{AA}$, were: $\mathrm{NaCl}$ $=\mathrm{KCl}=\mathrm{CaCl}_{2}<\mathrm{Na}_{2} \mathrm{CO}_{3}=\mathrm{K}_{2} \mathrm{CO}_{3}<\mathrm{H}_{2} \mathrm{SO}_{4}<$ Control $1<\mathrm{Control} 2<\mathrm{ZnCl}_{2}<\mathrm{MgCl}_{2} \cdot 6 \mathrm{H}_{2} \mathrm{O}$. The smaller the value of $n(1<n<10)$ the higher the adsorption intensity (Rozada et al., 2002; Weber Jr., 1973).

Table 3. Calculated $n$ and $k$ values of methylene blue adsorption from the Freundlich's isotherms.

\begin{tabular}{|c|c|c|}
\hline Sample $^{1}$ & $\mathrm{n}$ & $\mathrm{k}$ \\
\hline Control 1 & 2.85 & 6.83 \\
\hline Control 2 & 3.47 & 3.29 \\
\hline KSF-NaCI-AC & 1.69 & 16.50 \\
\hline KSF-KCI-AC & 1.69 & 16.50 \\
\hline $\mathrm{KSF}-\mathrm{CaCI}_{2}-\mathrm{AC}$ & 1.69 & 16.50 \\
\hline KSF-MgCI $-\mathrm{AC}$ & 11.99 & 1.46 \\
\hline $\mathrm{KSF}-\mathrm{Na}_{2} \mathrm{CO}_{3}-\mathrm{AC}$ & 2.20 & 10.40 \\
\hline $\mathrm{KSF}-\mathrm{K}_{2} \mathrm{CO}_{3}-\mathrm{AC}$ & 2.20 & 10.40 \\
\hline $\mathrm{KSF}-\mathrm{H}_{2} \mathrm{SO}_{4}-\mathrm{AC}$ & 2.31 & 9.36 \\
\hline $\mathrm{KSF}-\mathrm{ZnCI}-\mathrm{AC}$ & 4.93 & 4.68 \\
\hline
\end{tabular}

${ }^{\mathrm{i}}$ Control $1=$ Commercial powdered animal charcoal (Fischer Ltd. England). Control 2 = commercial granular AC (Steve Moore Chemical Company Zaria, Nigeria). $\mathrm{KSF}=$ Khaya senegalensis fruits. $\mathrm{AC}=$ activating agent.

The $k$ values, which indicate the adsorption capacities of the AC, ranks thus (in terms of the

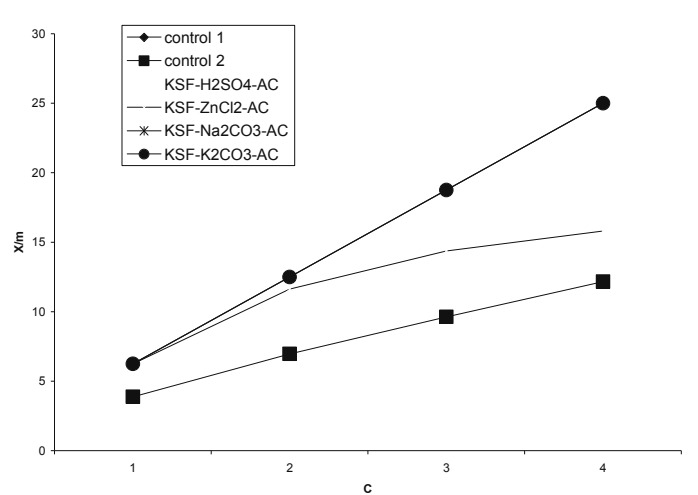

Figure 2. Adsorption isotherms of $\mathrm{MB}$ adsorption on controls (1 and 2), KSF-NaCl-AC, KSF-KCl-AC, and KSF$\mathrm{K} 2 \mathrm{CO} \cdot \mathrm{AC}$

AA): $\mathrm{NaCl}=\mathrm{KCl}=\mathrm{CaCl}_{2}>\mathrm{Na}_{2} \mathrm{CO}_{3}=\mathrm{K}_{2} \mathrm{CO}_{3}$ $>\mathrm{H}_{2} \mathrm{SO}_{4}>$ Control $1>\mathrm{ZnCl}_{2}>$ Control $2>$ $\mathrm{MgCl}_{2} \cdot 6 \mathrm{H}_{2} \mathrm{O}$. The greater the $k$ values the higher the adsorption capacity of an $\mathrm{AC}$ for the adsorbate. The previous sections on performance evaluation and adsorption isotherm show parity in the adsorption behavior of the Control 1 and some of the most effective KSF-AC carbons, for instance, $\mathrm{NaCl}, \mathrm{CaCl}_{2}, \mathrm{KCl}$ and $\mathrm{Na}_{2} \mathrm{CO}_{3}-\mathrm{AC}$ (Figure 1). However, the Freundlich isotherm parameters clearly showed that the newly produced KSF-AC activated with $\mathrm{NaCl}$ or $\mathrm{CaCl}_{2}$ or $\mathrm{KCl}$ have greater adsorption intensity and capacity than the commercial carbons. All the results consistently showed that $\mathrm{MgCl}_{2} \cdot 6 \mathrm{H}_{2} \mathrm{O}$ is not a good activating agent for $\mathrm{K}$. senegalensis fruit. This might be due to the presence of the molecules of water of crystallization which might have blocked the active sites for adsorption of the MB.

The breakthrough curves (Figures 3 and 4) show that, the control $1, \mathrm{NaCl}-\mathrm{AC}, \mathrm{CaCl}_{2}-\mathrm{AC}$, $\mathrm{Na}_{2} \mathrm{CO}_{3}-\mathrm{AC}$ and $\mathrm{K}_{2} \mathrm{CO}_{3}-\mathrm{AC}$ gave ideal curve, $\mathrm{KCl}$-AC, $\mathrm{H}_{2} \mathrm{SO}_{4}$ - $\mathrm{AC}$ and $\mathrm{ZnCl}_{2}$ - $\mathrm{AC}$ gave normal curves while the Control 2 and $\mathrm{MgCl}_{2} \cdot 6 \mathrm{H}_{2} \mathrm{O}$ $\mathrm{AC}$ gave abnormal curves. The Control 1, NaCl-AC, $\mathrm{CaCl}_{2}-\mathrm{AC}, \mathrm{Na}_{2} \mathrm{CO}_{3}$-AC and $\mathrm{K}_{2} \mathrm{CO}_{3}$-AC curves coincided along the concentration axis up to the highest value of $8 \mathrm{~mL}$ of MB solution. This means that the matrices have great enduring capacities (Mozammel and Masahirom, 1978). Amongst the KSF-AC, the NaCl-AC, $\mathrm{CaCl}_{2-} \mathrm{AC}, \mathrm{Na}_{2} \mathrm{CO}_{3}-\mathrm{AC}$ and $\mathrm{K}_{2} \mathrm{CO}_{3}-\mathrm{AC}$ have the greatest adsorbing endurance, followed by $\mathrm{KCl}$ $\mathrm{AC}, \mathrm{H}_{2} \mathrm{SO}_{4}-\mathrm{AC}$ and $\mathrm{ZnCl}_{2}-\mathrm{AC}$ and the least, $\mathrm{MgCl}_{2} \cdot 6 \mathrm{H}_{2} 0-\mathrm{AC}$. 


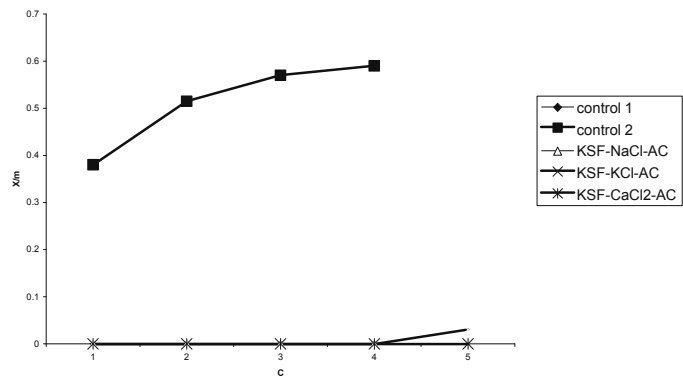

Figure 3. Breakhthrough curves of $\mathrm{MB}$ adsorption on controls (1 and 2), KSF-NaCl-AC, KSF-KCl-AC, and $\mathrm{Ca}$ C12-AC at $290 \mathrm{~K}$

The F values calculated were not significant $(\mathrm{p}<$ $0.01)$. Therefore differences between treatments were not statistically significant (Table 4).

The results obtained in this study have unequivocally proved that $K$. senegalensis fruit is a potential raw material for producing activated car-

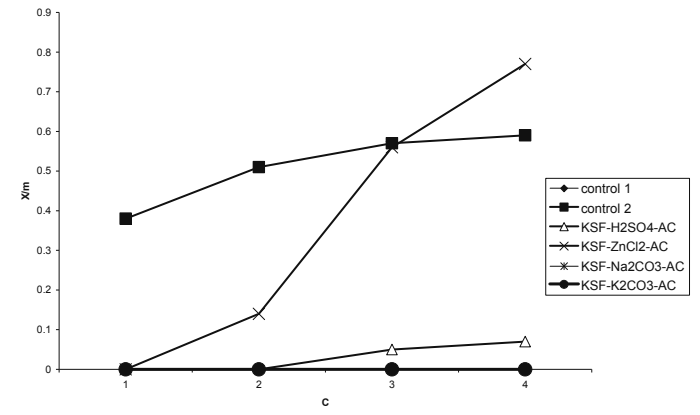

Figure 4. Breakhthrough curves of $\mathrm{MB}$ adsorption on controls (1 and 2), KSF-H2SO4-AC, KSF-ZnC12-AC, KSF$\mathrm{Na} 2 \mathrm{CO} 3-\mathrm{AC}$ and KSF-K2CO3-AC at $290 \mathrm{~K}$

bon. The adsorption capacity and intensity for MB outweigh those of the commercial products employed as controls in this study. The ready avalability of the raw material and the relatively cheap activating agents, especially $\mathrm{NaCl}$, suggest that the cost of production of the activated carbon will be relatively low.

Table 4. Results of the statistical analysis performed.

\begin{tabular}{llllll}
\hline & Mean methylene blue adsorbed & & & $\mathrm{CL}^{1}$ & $\mathrm{SE}^{1}$ \\
\hline Samples & Moles, $(\mathrm{X})^{1}$ & $\mathrm{SD}^{1}$ & $\mathrm{X} \pm 0.11$ & - & 0.02 \\
KSF-AC $^{2}$ & 1.104 & 0.06 & $\mathrm{X} \pm 0.04$ & 2.25 & 0.016 \\
\hline
\end{tabular}

${ }^{\mathrm{I}} \mathrm{X}$ is the mean of methylene blue (MB) adsorbed in moles by the respective samples. SD is the standard deviation. CL is the $95 \%$ confidence limit. F is the $\mathrm{F}$ test values calculated. $\mathrm{SE}$ is the standard error.

${ }^{2} \mathrm{KSF}-\mathrm{AC}=$ Khaya senegalensis fruits-activated carbon.

\section{Resumen}

C. E. Gimba, O. Ocholi, P. A. Egwaikhide, T. Muyiwa y E.E. Akporhonor. 2009. Nueva materia prima para carbón activado. I. Absorción del azul de metileno en carbón activado de frutos de Khaya senegalensis. Cien. Inv. Agr. 36(1):107-114. Carbón activado se preparó a partir de frutos de Khaya senegalensis. Las temperaturas de carbonización y activación fueron 500 y $800^{\circ} \mathrm{C}$, respectivamente, con un tiempo de exposición de 5 min para cada proceso. Los agentes activantes fueron $1 \mathrm{M}$ de $\mathrm{NaCl}, \mathrm{KCl}, \mathrm{CaCl}_{2}, \mathrm{MgCl}_{2} \cdot 6 \mathrm{H}_{2} \mathrm{O}, \mathrm{Na}_{2} \mathrm{CO}_{3}, \mathrm{~K}_{2} \mathrm{CO}_{3}$, $\mathrm{H}_{2} \mathrm{SO}_{4}$, o $\mathrm{ZnCI}_{2}$. El tamaño de partícula fue $125 \mu \mathrm{m}$. Los estudios de adsorción se realizaron empleando azul de metileno en solución acuosa como adsorbente a través de substratos fijos en microcolumnas. La información de equilibrio se analizó empleando parámetros de intensidad y capacidad de adsorción de las isotermas de Freundlich como también las curvas de quiebre. Los resultados se compararon con el comportamiento de carbón comercial de origen animal y carbón activado granulado. Los resultados sugieren que los frutos de $K$. senegalensis son apropiados como materia para producir carbón activado. El carbón activado con NaCI tuvo la mejor adsorción y resultó mejor que el producto comercial.

Key words: Adsorción, carbón, carbón activado, carbonización, isoterma, Khaya senegalensis. 


\section{References}

Abram, J.C. 1973. The characteristics of activated carbon. Pages 1-29. In: Proceeding of the Conferences Activated Carbon in Water Treatment. University of Reading, UK.

Giles, C.H., T.H. MacEwan, S.N. Nakhwa, and D. Smith. 1960. Studies in adsorption. Part XI. A system of classification of solution adsorption isotherms, and its use in diagnosis of adsorption mechanisms and measurement of specific surface areas of solids. J. Chem. Soc. 3:3973-3993.

Gimba, C.E , J.Y. Olayemi, S.T. Okunnu, and J.A. Kagbu. 2001. Adsorption of methylene blue by activated carbon from coconut shell. Global Journal of Pure and Applied Sciences 7:265-267.

Maroto-Valer, M., M. Zhe, L. Yinzhi, N.S. Zhang Brandon, J.M. Anderson, and H. Schobert. 2001. Enviromental benefits of producing adsorbent materials from unburned carbon. Pages 9-15. In: $4^{\text {th }}$ Int. Ash Utilization Symposium. Lexington, USA.

Mozammel, H.M., and O. Masahirom. 1978. Carbon Adsorption Handbook. Ann Arbor Science Publishers Inc., vol. 72, p. 689-690.
Mozammel, H.M., and O. Masahirom. 2002. Activated charcoal from coconut shell using $\mathrm{ZnCl}_{2}$ activation. Biomass and Bioener. 22:397-400.

Okieimen, F.E., and C.O. Eromosele, 1999. Fatty acid composition of the seed oil of Khaya senegalesis. Biosource Technology 69:279-280.

Rozada, F., L.F. Calvo, A.I. Garcia, J Martin-Villarcota, and M. Otero. 2002. Dye adsorption by sewage sludge based activated carbons in batch and fixed bed systems. Bioresource Technology 87:221-230.

Tsai, W.T., C.Y. Chang, C.F Wang, S.F Chien, and H.F. Sun. 2001. Preparation of activated carbons from corn cobs catalysed by potassium salts and subsequent gasification with $\mathrm{CO}_{2}$. Bioresource Technology 78:203-208.

von Maydell, H-J. 1990. Trees and Shrubs of the Sahel. Their Characteristics and Uses. Verlag Josef Margraf Scientific Books. GTZ . Germany. 525 pp.

Weber Jr., W.J. 1973.The Prediction of the performance of activated carbon for water treatment. Pages 53-71. In: Proceeding of the conference Activated Carbon in Water Treatment. Water Research Association. University of Reading, UK. 
